\title{
Effect of Nickel Administration in vivo on the Testicular Structure in Male Mice
}

\section{P. MASSÁNYI, N. LUKÁČ, J. ZEMANOVÁ, A. V. MAKAREVICH ${ }^{1}$, P. CHRENEK $^{1}$, V. CIGÁNKOVÁ ${ }^{2}$, S. FLEŚÁROVÁ ${ }^{2}$, R. TOMAN, ZS. FORGÁCS ${ }^{3}$, Z. SOMOSY ${ }^{3}$, P. LAZOR}

Slovak University of Agriculture, Nitra, Slovak Republic

${ }^{1}$ Slovak Agricultural Research Centre, Nitra, Slovak Republic

${ }^{2}$ University of Veterinary Medicine, Košice, Slovak Republic

${ }^{3}$ Fodor József National Center of Public Health, Budapest, Hungary

Received March 9, 2006

Accepted January 4, 2007

\begin{abstract}
Massányi P., N. Lukáč, J. Zemanová, A. V. Makarevich, P. Chrenek, V. Cigánková, S. Flešárová, R. Toman, ZS. Forgács, Z. Somosy, P. Lazor: Effect of Nickel Administration in vivo on the Testicular Structure in Male Mice. Acta Vet Brno 2007, 76: 223-229.

The aim of this study was to describe the effects of nickel $\left(\mathrm{NiCl}_{2}\right)$ on murine testicular structure. Experimental animals were injected intraperitoneally with a single dose of $20 \mathrm{mg} \mathrm{NiCl} 2$ per $\mathrm{kg}$ of body mass (group $\mathrm{A}, \mathrm{n}=5$ ) and $40 \mathrm{mg} \mathrm{NiCl}_{2}$ per $\mathrm{kg} \mathrm{b}$. $\mathrm{m}$. (group $\mathrm{B}, \mathrm{n}=5$ ). The group without injection ( $\mathrm{n}=5$ ) was the control (C). Animals were killed 48 hours after administration of nickel. The body mass of animals, the mass of testes and the testes : body mass ratio were not significantly affected. In both experimental groups a significant $(p<0.001)$ decrease of germinal epithelium in comparison with control group was observed. The relative volume of the interstitium was increased but not significantly in both experimental groups. An increase in the relative volume of the lumen was registered in both experimental groups in comparison with the control group. The qualitative analysis detected a dilatation of blood vessels in the interstitium, undulation of the basal membrane and several empty spaces in the germinal epithelium. The diameter $(n=150)$ of the seminiferous tubule was markedly $(p<0.05)$ decreased in both experimental groups $(\mathrm{A}, \mathrm{B})$ compared to control group. The height of the germinal epithelium showed a significant decrease $(p<0.05-0.001)$ after nickel administration. Evaluation of the lumen diameter in the seminiferous tubule showed a significant increase in both experimental groups. The data of the perimeter of seminiferous tubules corresponded with those of the seminiferous tubule diameter. TUNEL assay detected a higher frequency of localized apoptosis in the interstitium of nickel-administered animals compared to control group. Our findings clearly suggest a negative effect of nickel on the structure as well as on the function of the seminferous epithelium at the site of spermatozoa production.
\end{abstract}

Nickel, testis, toxicology, histology, morphometry, apoptosis

Nickel is a naturally occurring element that may exist in various mineral forms. It is used in a variety of applications including metallurgic processes and in electrical components, such as batteries (ATSDR 1988; USAF 1990). Some evidence suggests that nickel may be an essential trace element for mammals.

The absorption of nickel is dependent on its physicochemical form, with water soluble forms being more readily absorbed. The metabolism of nickel involves conversion to various chemical forms and binding to various ligands (ATSDR 1988). Nickel is excreted in the urine and faeces with relative amounts for each route of exposure and chemical form. Most nickel enters the body via food and water consumption, although inhalation exposure in occupational settings is the primary route for nickel-induced toxicity (Ankel-Fuchs and Thauer 1988).

In large doses some forms of nickel may be acutely toxic to humans when taken orally (Daldrup et al. 1983; Sunderman et al. 1988). Toxic effects of oral exposure to nickel usually involve the kidneys, with some evidence from animal studies showing a possible

Address for correspondence:

Peter Massányi, DVM, PhD

Department of Animal Physiology

Slovak University of Agriculture, Tr. A. Hlinku 2

SK-94976 Nitra, Slovak Republic
Phone: +421-37-6508 284

Fax: +421-37-411 541

E-mail: massanyi@yahoo.com

http://www.vfu.cz/acta-vet/actavet.htm 
impairment of development and reproductive functions (ATSDR 1988; Goy er 1991).

Data on nickel-induced reproductive and developmental effects in humans following exposure are equivocal. No clinical evidence of developmental or reproductive toxicity was reported for women working in a nickel refinery (Warner 1979). On the other hand, possible reproductive and developmental effects in humans occupationally exposed to nickel were reported (Chashschin et al. 1994; Coogan et al. 1989; Costa 1991; Oller et al. 1997).

In the testes of laboratory animals nickel salts induced morphological changes such as degeneration of testicular germinal epithelium, testicular sarcomas and functional disorders - inhibition of spermatogenesis or complete sterility and decrease of testosterone production (Mathur et al. 1977; Lee 1983). In the rat interstitial (Leydig) cell culture, dosedependent depression in both hCG- and cAMP-stimulated testosterone production was seen after $\mathrm{Ni}^{2+}$ treatment (Laskey and Phelps 1991; Forgács et al. 1998, 2001).

The aim of this study was to describe and quantify structural and functional changes in the testes of mice after an intraperitoneal administration of nickel.

\section{Materials and Methods}

All experiments were conducted on adult (3-month-old) male mice (ICR, Mus musculus albicans) in the accredited experimental laboratory at the Slovak Agricultural University in Nitra (Protocol No. 4345/00-220 and Decree MP SR No. 231/1998). The animals $(n=15)$ were divided into 3 groups $(A, B, C)$. Five animals (group A) were injected intraperitoneally with a single dose of $20 \mathrm{mg} \mathrm{NiCl}_{2}$ per $\mathrm{kg}$ of body mass. Other five animals (group B) received a single dose of $40 \mathrm{mg} \mathrm{NiCl}_{2}$ per body mass. Animals were killed 48 hours after administration of nickel $\left(\mathrm{NiCl}_{2}\right.$, Sigma, St. Louis, MO). The animals were weighed before and after the experiment. Selected visceral organs were weighed as well, with the accuracy of $\pm 0.1 \mathrm{~g}$. Nickel was diluted with a physiological solution to the appropriate concentration (volume $=0.25 \mathrm{ml}$ ). Food (pelletized food mixture KKD - O/10) and water were available for all animals ad libitum. The last group (C) was the control without nickel injection. After euthanasia, visceral organs were weighed and the testes of nickel-treated and untreated mice were fixed in $10 \%$ formol, dehydrated in a graded series of ethanol and embedded in paraffin wax. Whole testes were sectioned on a microtome. The serial 4 - $5 \mu \mathrm{m}$ thick sections were stained with haematoxylin and eosin. At least five sections from each animal were measured using a light microscope (Carl Zeiss NU-2) and software for analysis Image ProPlus (Media Cybernetic). The relative volume of the germinal epithelium, interstitium and lumen; the diameter of the seminiferous tubule; the height of the germinal epithelium; the diameter of the lumen of the seminiferous tubule and the perimeter (circumference) of the seminiferous tubule $(\mu \mathrm{m})$ were measured with respect to each testis, based on micromorphological criteria (Weibel et al. 1966; Massányi et al. 2000; Toman et al. 2002).

From the final data, basic statistical characteristics (mean, standard deviation, variation, median, minimum, maximum values) were calculated using PC program SPSS 11.0.1 (ID 112285) and the differences between groups were analyzed by F-test at the level of significance of $p<0.05$.

For the apoptosis assay MEBSTAIN Apoptosis kit Direct (Immunotech, France) was used to detect TUNEL reactions. After fixation in $4 \%$ paraformaldehyde, $3-5 \mu \mathrm{m}$ thick sections were prepared for staining. The samples were deparaffanized using xylene and ethanol $(100-80 \%)$ and treated with proteinase $\mathrm{K}\left(\mathrm{PK}^{+}\right)$. DNA nick end was labelled using TdT reaction, counterstained with DAPI stain and mounted. After the procedure the samples were analyzed on the Leica fluorescent microscope.

\section{Results}

No significant differences were detected in the body mass of animals before experiment (Time 0 ) and after the nickel administration (Time 48). Also the mass of testes and the testes: body mass ratio was not significantly affected (Table 1).

In control animals the testes were completely enclosed by the tunica albuginea which was thickened posteriorly to form the mediastinum of testis, projecting somewhat into the body of the testis. Blood vessels and lymphatic vessels and the channels carrying spermatozoa passed through this area. Fibrous septa form the mediastinum divided the body of the testis into lobules; each lobule contained seminiferous tubules. Each seminiferous tubule had a central lumen lined by an actively replicating germinal epithelium mixed with a population of supporting sustentacular cells. Between seminiferous tubules the interstitium containing interstitial cells and blood vessels was present. 
Table 1. Body mass of animals, selected organs and mass ratios

\begin{tabular}{|c|c|c|c|c|c|}
\hline Group & $\mathrm{x}$ & sd & median & minimum & maximum \\
\hline \multicolumn{6}{|c|}{ Body mass of animals at Time $0(\mathrm{~g})$} \\
\hline $\mathrm{C}$ & 41.04 & 2.90 & 41.70 & 36.20 & 43.60 \\
\hline $\mathrm{A}$ & 36.42 & 3.48 & 37.00 & 31.50 & 40.40 \\
\hline B & 31.78 & 6.86 & 34.50 & 22.80 & 39.70 \\
\hline \multicolumn{6}{|c|}{ Body mass of animals at Time $48(\mathrm{~g})$} \\
\hline $\mathrm{C}$ & 37.72 & 2.26 & 38.20 & 34.70 & 40.60 \\
\hline $\mathrm{A}$ & 35.20 & 3.22 & 35.90 & 30.60 & 38.50 \\
\hline $\mathrm{B}$ & 27.82 & 6.13 & 29.60 & 19.80 & 33.90 \\
\hline \multicolumn{6}{|c|}{ Testes $(\mathrm{g})$} \\
\hline $\mathrm{C}$ & 0.40 & 0.06 & 0.42 & 0.30 & 0.44 \\
\hline A & 0.35 & 0.07 & 0.32 & 0.30 & 0.46 \\
\hline B & 0.32 & 0.09 & 0.34 & 0.30 & 0.43 \\
\hline \multicolumn{6}{|c|}{ Testes : Animal body mass $(\times 100)$} \\
\hline $\mathrm{C}$ & 1.05 & 0.10 & 1.09 & 0.86 & 1.10 \\
\hline A & 1.00 & 0.12 & 0.98 & 0.89 & 1.19 \\
\hline B & 1.14 & 0.10 & 1.13 & 1.06 & 1.31 \\
\hline
\end{tabular}

$\mathrm{x}$ - mean; sd - standard deviation

Table 2. Relative volume of germinal epithelium, interstitium and lumen

\begin{tabular}{|l|c|c|c|c|c|}
\hline Group & $\mathrm{x}$ & $\mathrm{sd}$ & median & minimum & maximum \\
\hline \multicolumn{7}{|c|}{ Germinal epithelium (\%) } \\
\hline C & 79.95 & 2.06 & 79.64 & 77.14 & 83.93 \\
\hline A & 75.12 & 4.50 & 75.00 & 65.50 & 83.22 \\
\hline B & 70.17 & 5.60 & 70.17 & 58.21 & 81.43 \\
\hline \multicolumn{7}{|l|}{ Interstitium (\%) } \\
\hline C & 6.36 & 2.11 & 6.43 & 3.57 & 12.14 \\
\hline A & 9.69 & 3.99 & 8.21 & 4.29 & 16.43 \\
\hline B & 13.57 & 5.70 & 12.86 & 7.50 & 31.79 \\
\hline \multicolumn{7}{|l|l|l|}{ Lumen (\%) } \\
\hline C & 13.69 & 3.07 & 13.22 & 7.50 & 18.22 \\
\hline A & 15.19 & 5.11 & 14.29 & 7.14 & 25.36 \\
\hline B & 16.26 & 4.05 & 16.79 & 10.00 & 22.14 \\
\hline
\end{tabular}

$\mathrm{x}$ - mean; sd - standard deviation

Germinal epithelium: C:A $p<0.001, \mathrm{C}: \mathrm{B} p<0.001, \mathrm{~A}: \mathrm{B} p<0.05$

Interstitium, Lumen: $p>0.05$

The largest relative volume of the germinal epithelium $(79.95 \pm 2.06 \%)$ was observed in the control group (Table 2). In both experimental groups a significant $(p<0.001)$ decrease in comparison with the control group was detected. Also a significant $(p<0.05)$ difference between groups A and B was detected. Generally, the decrease of the relative volume of the germinal epithelium reached almost $10 \%$. The relative volume of the intersitium was increased in both experimental groups, but the differences were not significant. An increase of the relative volume of the lumen was registered in both experimental groups in comparison with the control group. Qualitative analysis detected dilatation of blood vessels in the interstitium, undulation of the basal membrane and some empty spaces in the germinal epithelium (Plates V, VI, Figs 1 - 4). Our findings clearly suggest a negative effect of nickel on the structure as well as function of the seminiferous epithelium in the place of spermatozoa production. Also the TUNEL assay detected a higher frequency of apoptosis 
in the interstitium of nickel-administered animals (Plate VII, Fig. 5b) in comparison with the control group (Plate VII, Fig. 5a).

In evaluation of the diameter of the seminiferous tubule we found a significant decrease of this variable in both experimental groups (A, B) in comparison with the control group (Table 3). Also the height of the germinal epithelium showed a significant decrease after nickel administration, ranging from 60.55 to $48.78 \mu \mathrm{m}$. Evaluation of the lumen diameter in the seminiferous tubule showed a significant increase in both experimental groups. In all experimental groups we found increased luminiziation (Table 2) of the seminiferous tubule with increased relative volume of the lumen (Table 1). The resulting data on the perimeter of seminiferous tubules correspond with those on the seminiferous tubule diameter.

Table 3. Diameter of seminiferous tubule, height of germinal epithelium, diameter of lumen and perimeter of seminiferous tubule

\begin{tabular}{|c|c|c|c|c|c|}
\hline Group & $\mathrm{x}$ & $\mathrm{sd}$ & median & minimum & maximum \\
\hline \multicolumn{7}{|c|}{ Diameter of seminiferous tubule $(\mu \mathrm{m})$} \\
\hline C & 231.49 & 27.12 & 230.50 & 188.10 & 293.53 \\
\hline A & 212.94 & 32.08 & 207.32 & 151.84 & 276.09 \\
\hline B & 191.36 & 30.50 & 201.38 & 130.63 & 236.36 \\
\hline \multicolumn{7}{|c|}{ Height of germinal epithelium $(\mu \mathrm{m})$} \\
\hline C & 60.55 & 10.93 & 62.91 & 34.55 & 75.12 \\
\hline A & 54.86 & 8.79 & 53.50 & 41.18 & 83.69 \\
\hline B & 48.78 & 8.58 & 47.55 & 30.33 & 65.19 \\
\hline \multicolumn{7}{|l|}{ Diameter of lumen of seminiferous tubule $(\mu \mathrm{m})$} \\
\hline C & 84.16 & 29.15 & 85.49 & 20.76 & 131.22 \\
\hline A & 97.32 & 26.12 & 106.07 & 47.43 & 136.71 \\
\hline B & 103.78 & 22.16 & 107.64 & 69.91 & 165.92 \\
\hline \multicolumn{7}{|l|}{ Perimeter of seminiferous tubule $\left(\mu m^{2}\right)$} \\
\hline C & 998.96 & 114.26 & 1014.24 & 816.13 & 1321.11 \\
\hline A & 924.24 & 72.89 & 921.74 & 796.13 & 1077.49 \\
\hline B & 836.48 & 87.44 & 846.48 & 626.35 & 1023.46 \\
\hline
\end{tabular}

$\mathrm{x}$ - mean; sd - standard deviation

Diameter of seminiferous tubule: C:A $p<0.05$; C:B $p<0.001$; A:B $p<0.05$

Height of germinal epitelium: $\mathrm{C}: \mathrm{A} p<0.05 ; \mathrm{C}: \mathrm{B} p<0.001 ; \mathrm{A}: \mathrm{B} p<0.05$

Diameter of lumen of seminferous tubule: $\mathrm{C}: \mathrm{A} p>0.05 ; \mathrm{C}: \mathrm{B} p<0.01 ; \mathrm{A}: \mathrm{B} p>0.05$

Perimeter of seminiferous tubule: C:A $p<0.01$; $\mathrm{C}: \mathrm{B} p<0.001$; A:B $p<0.001$

\section{Discussion}

Nickel has been demonstrated to destroy regular testicular structure and a dose-dependent alteration in almost all morphometric indicators. Our results showed an increase in the relative volume of the interstitium related to the diapedesis and also a decrease of germinal epithelium. These data suggest alterations of spermatogenesis directly affecting epithelium and/or influencing interstitial cells (increased ratio of apoptosis) producing testosterone. This probably caused alterations in steroidogenesis, and subsequently, spermatogenesis was seriously affected.

A significant decrease in absolute and organ-to-body mass ratios of testes, epididymides, seminal vesicles and prostate gland after oral administration of nickel sulphate was found (Pandey et al. 1999). The spermatozoa abnormality, associated with a decrease in spermatozoa motility and sperm count was also observed. Significant alterations in the activities of marker testicular enzymes associated with histopathological changes in testes, epididymides and seminal vesicles were also 
observed. This study reveals that the oral exposure to nickel may affect the histology of testes, epididymides, seminal vesicles and spermatozoa morphology. In other experiments, the final mean body weights of various nickel sulphate-treated rats were not significantly decreased except for the $0.1 \%$ nickel sulphate-treated group, when compared to the control (Obone et al. 1999). The absolute and relative organ weights were either increased or decreased or remained unchanged, depending on the organ and the dose of nickel sulphate. The relative order of bioaccumulation of nickel in different organs of rats when treated with $0.1 \%$ nickel sulphate was as follows: kidneys $>$ testes $>$ lung $=$ brain $>$ spleen $>$ heart $=$ liver .

Testosterone production of mouse interstitial cells in vitro following an in vivo or in vitro nickel exposure was evaluated byForgács et al. (1998). Dose-dependent depression in hCG-stimulated testosterone production was seen at a nickel dose of $125 \mu \mathrm{M}$ or higher. Results of this study show a dose-related depression in stimulated testosterone production and indicate that the effect is both time- and concentration-dependent and not due to cytotoxicity. A significant reduction in the activities of testicular steroidogenic enzymes and plasma testosterone concentration accompanied by a significant change in cholesterol and ascorbic acid level was observed (Pandey et al. 1999; Das and Dasgupta 2000). Also Monsees et al. (1998) have examined the effect of nickel on the viability, mitochondrial dehydrogenase activity and secretory function of rat sustentacular (Sertoli) cells. Noncytotoxic concentration of nickel significantly increased lactate production. No changes in inhibin levels were observed in the presence of nickel. Nickel caused significant changes in some sustentacular cell secretion products. Forgács et al. (2001) investigated the efficacy of two nickel-binding amino acids, histidine and cysteine, in preventing the inhibitory action of nickel on testosterone production by mouse primary interstitial cell culture. Nickelinduced reduction in testosterone production was completely prevented by equimolar concentrations of His at $\mathrm{Ni}^{2+}$ concentrations of 125,250 , and $500 \mu \mathrm{M}$; equimolar or twice the equimolar concentrations of His were only partially effective at $1000 \mu \mathrm{M} \mathrm{Ni}{ }^{2+}$. Protective action of Cys was complete only at the lowest concentration of $\mathrm{Ni}^{2+}$. Increasing the time of incubation, the protective effect of both amino acids against $\mathrm{Ni}^{2+}$ was reduced. A partial recovery of hCG- stimulated testosterone production could be observed only if the amino acid was added no later than 4 hours after the metal. Administration of these amino acids after the $\mathrm{Ni}^{2+}$-produced decrease in testosterone production notably reversed the process.

Our results clearly document the negative effect of nickel on spermatogenesis. The decrease in the relative volume of germinal epithelium indicates alterations in spermatozoa production.

In our previous studies (Massányi et al. 2003, 2004a) we reported that the level of seminal nickel is significantly higher in fox and ram $\left(0.31 \pm 0.19 \mathrm{mg} \cdot \mathrm{kg}^{-1}\right)$ in comparison with bull $\left(0.12 \pm 0.07 \mathrm{mg} \cdot \mathrm{kg}^{-1}\right)$ and boar $\left(0.06 \pm 0.08 \mathrm{mg} \cdot \mathrm{kg}^{-1}\right)$. The concentration of nickel in the semen of stallion was $0.20 \pm 0.24 \mathrm{mg} \cdot \mathrm{kg}^{-1}$. A highly negative correlation between seminal nickel and copper in the ram was found. Correlation analysis in bulls as well as rams showed a high positive relation between nickel and separated tail (Mas sányi et al. 2004b).

On the other hand, Y ok oi et al. (2003) reported that nickel affects cyclic nucleotide gated channels $(\mathrm{CNG})$ that are important in spermatozoa physiology. Nickel deprivation significantly decreased spermatozoa motility and density in the epididymides, epididymal transit time of spermatozoa, and testes spermatozoa production rate. Nickel deficiency also significantly decreased the weights of the seminal vesicles and prostate glands.

Although short-term doses of nickel induced only a minimal lipid peroxidation response (LPO), multiple doses elicited a moderate increase in LPO in whole homogenates and higher dose-related increases in both mitochondrial and microsomal fractions (Doreswamy et al. 2004). 
This was associated with a significant increase in DNA damage in the testis as evidenced by increased single-strand breaks. These findings suggest that testicular toxicity of nickel compounds may be related to enhanced production of reactive oxygen species, probably mediated through oxidative damage to macromolecules, including the damage of DNA.

All detected results suggest that nickel has a negative effect on the testicular structure, affecting mainly spermatozoa development as well as steroidogenesis.

\section{Účinok niklu podaného in vivo na štruktúru semenníka myších samcov}

V práci sa sledoval vplyv niklu $\left(\mathrm{NiCl}_{2}\right)$ na štruktúru semenníka u myší. Zvieratá boli rozdelené na tri skupiny, ktoré intraperitoneálne dostali jednorazovú dávku $20 \mathrm{mg} \mathrm{NiCl} \cdot \mathrm{kg}^{-1}$ živej hmotnosti (skupina A), $40 \mathrm{mg} \mathrm{NiCl} \cdot \mathrm{kg}^{-1}$ (group B) a skupina C bez podania niklu slúžila ako kontrola. Zvieratá boli usmrtené 48 h po podaní niklu. Váženie nepreukázalo žiadne preukazné rozdiely v hmotnosti zvierat pred pokusom a po podaní niklu. Nezistil sa ani rozdiel v pomere hmotnosti semenníkov v celkovej hmotnosti. V oboch pokusných skupinách sme zistili preukazný $(p<0,001)$ pokles relatívneho objemu semenotvorného epitelu v porovnaní s kontrolou. Podobne sa zistil aj preukazný $(p<0,05)$ rozdiel medzi skupinou A a B. Relatívny objem interstícia bol nepreukazne vyšší v oboch pokusných skupinách. Relatívny objem bol vyšší po podaní niklu. Kvalitatívnym hodnotením sa zistila dilatácia krvných ciev v interstíciu, undulácia bazálnej membrány a v semenotvornom epiteli sa vyskytovali prázdne miesta. Priemer semenotvorného kanálika bol preukazne vyšší v oboch pokusných skupinách v porovnaní s kontrolou. Podobne výška semenotvorného epitelu preukazovala výrazný pokles po podaní niklu. Naopak, hodnotenie priemeru lúmenu semenotvorného kanálika bol signifikantne vyššie v oboch pokusných skupinách. TUNEL analýza preukázala vyššiu frekvenciu apoptózy v interstíciu zvierat po podaní niklu v porovnaní s kontrolnou skupinou. Dosiahnuté výsledky jasne dokazujú negatívny účinok niklu na štruktúru ako aj funkciu semenotvorného epitelu s hladiska produkcie spermií.

\section{Acknowledgement}

This study was supported with VEGA grant No. 1/2417/05 of the Slovak Ministry of Education.

\section{References}

ANKEL-FUCHS D, THAUER RK 1988: Nickel in biology: Nickel as an essential trace element. In: LANCASTER JR (Ed.): The bioorganic chemistry of nickel. VHC: New York, pp. 93-110

ATSDR (Agency for Toxic Substances and Disease Registry) 1988: Toxicological Profile for Nickel. ATSDR/U.S: Public Health Service, ATSDR/TP-88/19

CHASHSCHIN VP, ARTUNINA PA, NORSETH T 1994: Congenital defects, abortion and other health effects in nickel refinery workers. Sci Total Environ 148: 287-291

COOGAN TP, LATTA DM, SNOW ET, COSTA M 1989: Toxicity and carcinogenicity of nickel compounds. CRC Crit Rev Toxicol 19: 341-384

COSTA M 1991: Molecular mechanism of nickel carcinogenesis. Annu Rev Pharmacol Toxicol 31: $321-337$

DALDRUP T, HAARHOFF K, SZATHMARY SC 1983: Toedliche nickel sulfate-intoxikation. Ber Gericht Med 41: $141-144$

DAS KK, DASGUPTA S 2000: Effect of nickel on testicular nucleic acid concentrations of rats on protein restriction. Biol Trace Elem Res 73: 175-180

DORESWAMY K, SHRILATHA B, RAJESHKUMAR T, MURALIDHARA V 2004: Nickel-induced oxidative stress in testis of mice: Evidence of DNA damage and genotoxic effects. J Androl 25: 996-1003

FORGÁCS Z, PAKSY K, LAZAR P, TATRAI E 1998: Effect of $\mathrm{Ni}^{2+}$ on the testosterone production of mouse primary Leydig cell culture. J Toxicol Environ Health A 55: 101-112

FORGÁCS Z, NEMETHY Z, REVESZ C, LAZAR P 2001: Specific amino acids moderate the effects of $\mathrm{Ni}^{2+}$ on the testosterone production of mouse Leydig cells in vitro. J Toxicol Environ Health A 62: 349-358

GOYER R 1991: Toxic effects of metals. In: Casarett and Doull's Toxicology, 4th ed. AMDUR MO, DOULL JD, KLAASSEN CD (Eds). Pergamon Press, New York, pp. 623-680

LASKEY JW, PHELPS PV 1991: Effects of cadmium and other metal cations on in vitro Leydig cell testosterone production. Toxicol Appl Pharmacol 108: 296-306 
LEE IP 1983: Effects of environmental metals on male reproduction. In: CLARKSON TW, NORDBERG GF, SAGER PR (Eds): Reproductive and Developmental Toxicity of Metals. Plenum Press, New York, London, pp. 253-278

MASSÁNYI P, SLAMEČKA J, LUKÁČ N, JURČÍK R 2000: Seasonal variations in the morphometric analysis of the testis, testosterone production, and occurrence of pathological spermatozoa in the brown hare (Lepus europaeus). J Anim Feed Sci 9: 709-719

MASSÁNYI P, TRANDŽÍK J, NAĎ P, TOMAN R, SKALICKÁ M, KORÉNEKOVÁ B. 2003: Seminal concentrations of trace elements in various animals and their correlations. Asian J Androl 5: 101-104

MASSÁNYI P, TRANDŽÍK J, NAĎ P, LUKÁČ N, SKALICKÁ M, KORÉNEKOVÁ B, CIGÁNKOVÁ V, TOMAN R, HALO M, STRAPÁK P 2004a: Semen concentration of trace elements in stallions and relation to the spermatozoa quality. Trace Elem Electrolytes 21: 229-231

MASSÁNYI P, TRANDŽÍK J, NAĎ P, KORÉNEKOVÁ B, SKALICKÁ M, TOMAN R, LUKÁČ N, HALO M, STRAPÁK P 2004b: Concentration of copper, iron, zinc, cadmium, lead, and nickel in bull and ram semen and relation to the occurrence of pathological spermatozoa. J Environ Sci Health A39: 3005-3014

MATHUR AK, DATTA KK, TANDON SK, DIKSHITH TSS 1977: Effect of nickel sulfate on male rats. Bull Environ Contam Toxicol 17: 241-248

MONSEES TK, WINTERSTEIN U, HAYATPOUR J, SCHILL WB, MISKA W 1998: Effect of heavy metals on the secretory function of testicular cells in culture. J Trace Microprobe Tech 16: 427- 435

OBONE E, CHAKRABARTI SK, BAI CJ, MALICK MA, LAMONTAGNE L, SUBRAMANIAN KS 1999: Toxicity and bioaccumulation of nickel sulfate in Sprague-Dawley rats following 13 weeks of subchronic exposure. J Toxicol Environ Health A57: 379-401

OLLER AR, COSTA M, OBERDOSTER G 1997: Carcinogenicity assessment of selected nickel compounds. Toxicol Appl Pharmacol 143: 152-166

PANDEY R, KUMAR R, SINGH SP, SAXENA DK, SRIVASTAVA SP 1999: Male reproductive effect of nickel sulphate in mice. Biometals 12: 339-346

SUNDERMAN FW, DINGLE B, HOPFER SM, SWIFT T 1988: Acute nickel toxicity in electroplating workers who accidentally ingested a solution of nickel sulfate and nickel chloride. Am J Indust Med 14: 257-266

TOMAN R, MASSÁNYIP, UHRÍN V 2002: Changes in the testis and epididymis of rabbits after an intraperitoneal and peroral administration of cadmium. Trace Elem Electrolytes 19: 114-117

USAF 1990: Nickel. In: Installation Restoration Program Toxicology Guide, Vol. 5. Harry G. Armstrong Aerospace Medical Research Laboratory, Wright Patterson AFB, OH

WARNER JS 1979: Nickel carbonyl. Prenatal exposure. Science $203: 1194-1195$

WEIBEL ER, KISTLER GS, SCHERLE WF 1966: Practical stereological methods for morphometric cytology. J Cell Biol 30: 33-38

YOKOI K, UTHUS EO, NIELSEN FH 2003: Nickel deficiency diminishes sperm quantity and movement in rats. Biol Trace Elem Res 93: 141-153 
Plate V

Massányi P. et al.: Effect of Nickel ... pp. 223-229

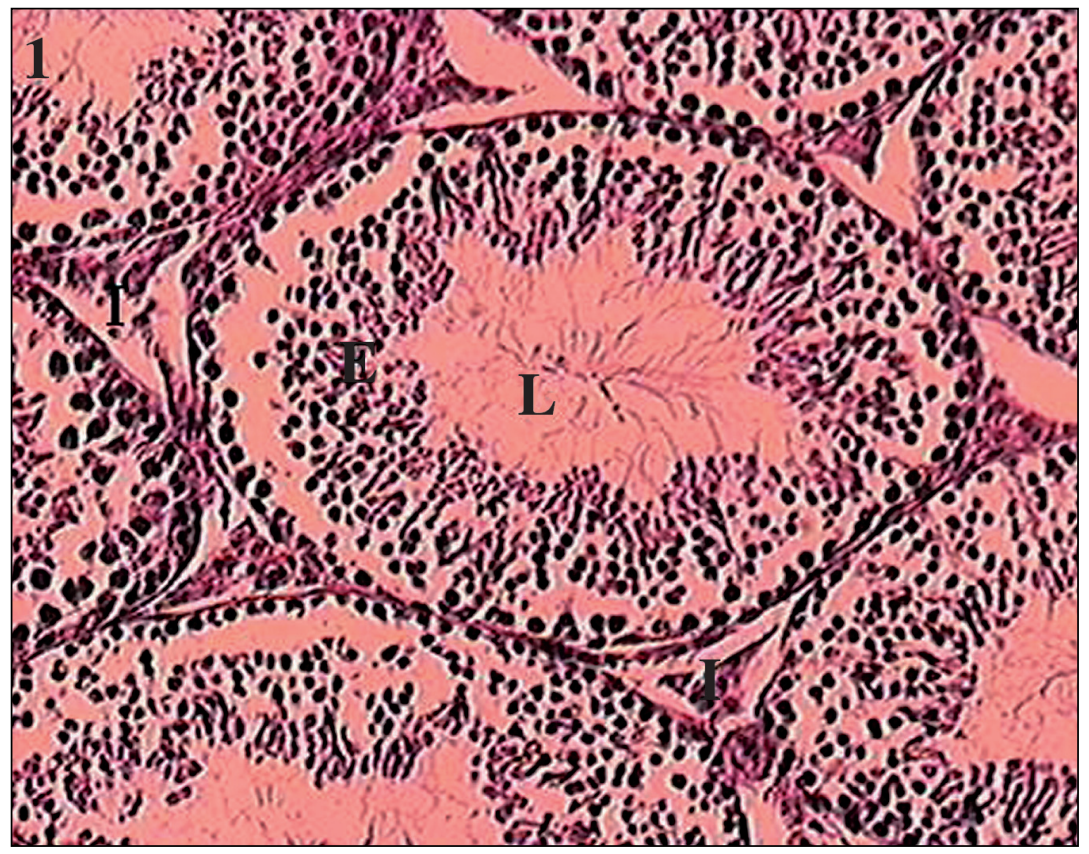

Fig. 1. Microscopic structure of testis in control mice. Seminiferous tubules consist of germinal epithelium (E) and central lumen (L). Between the tubules the interstitium (I) is present.

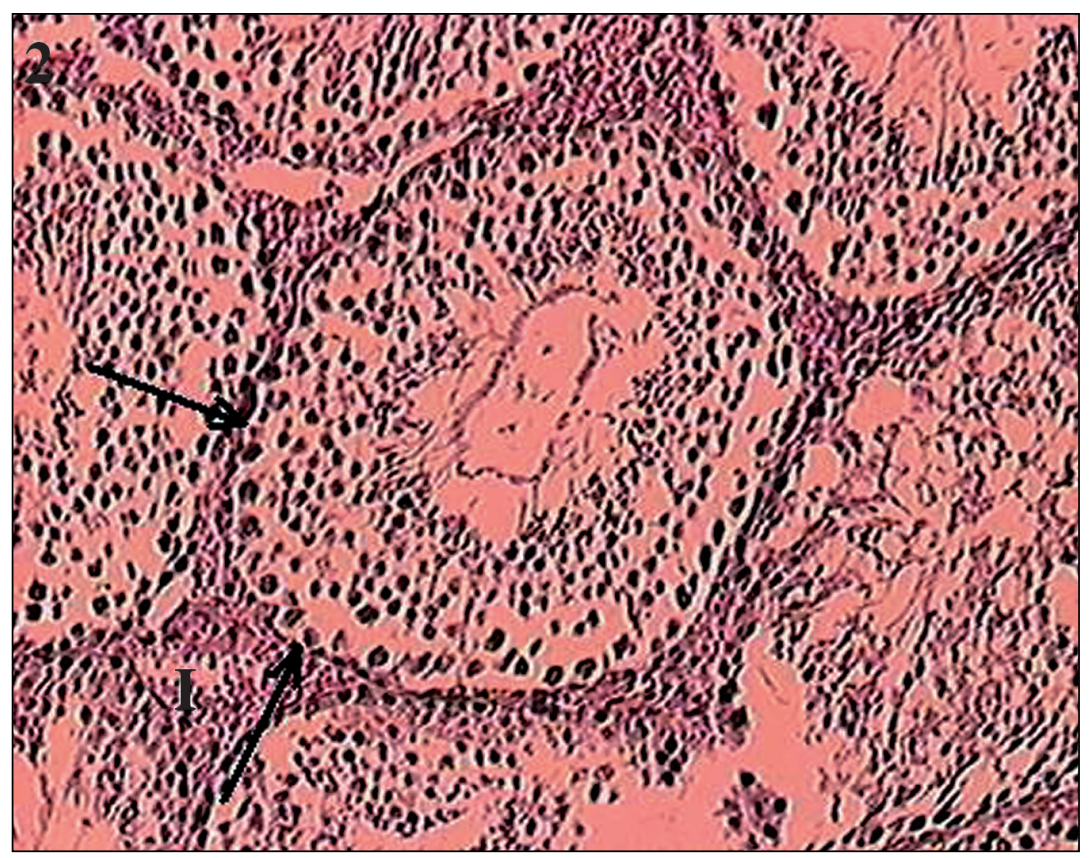

Fig. 2. After a lower nickel dose administration, undulation (arrows) of the basal membrane of the seminiferous tubule was detected. Also the relative volume of the interstitium (I) has increased. 


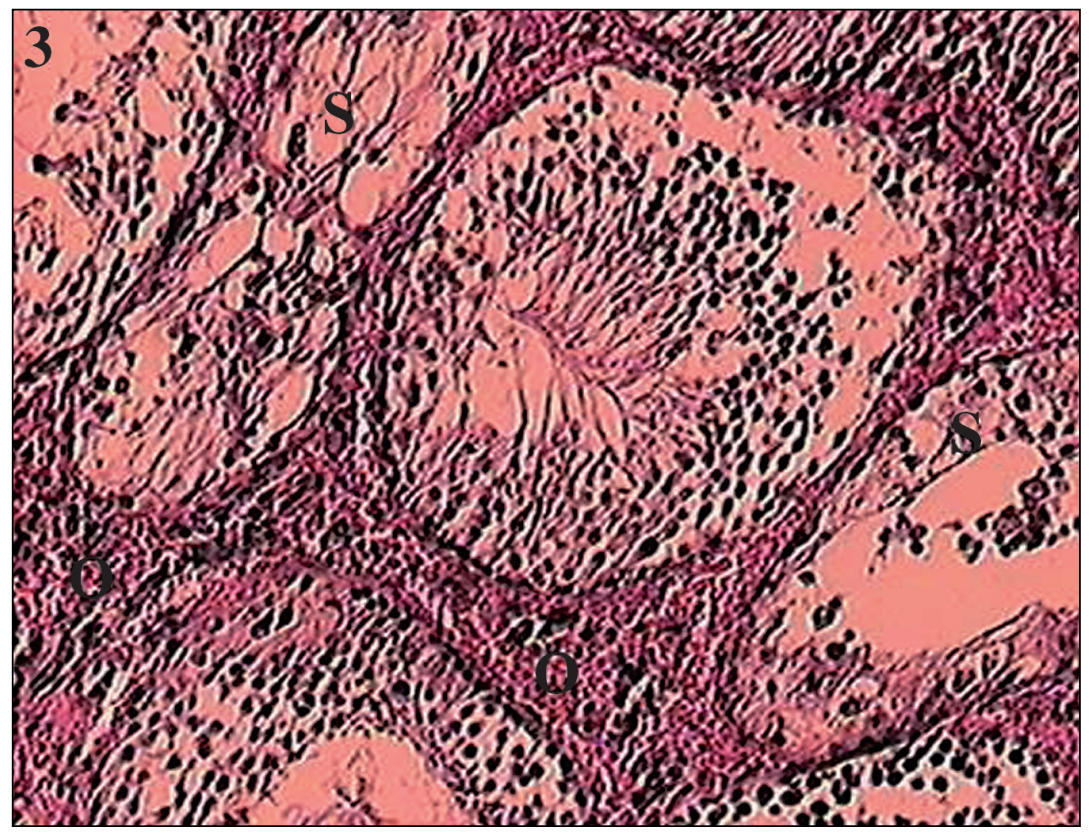

Fig. 3. In the testicular structure of animals in the group with higher nickel administration alterations including oedema $(\mathrm{O})$ of the interstitium and empty spaces (S) in the germinal epithelium were found.

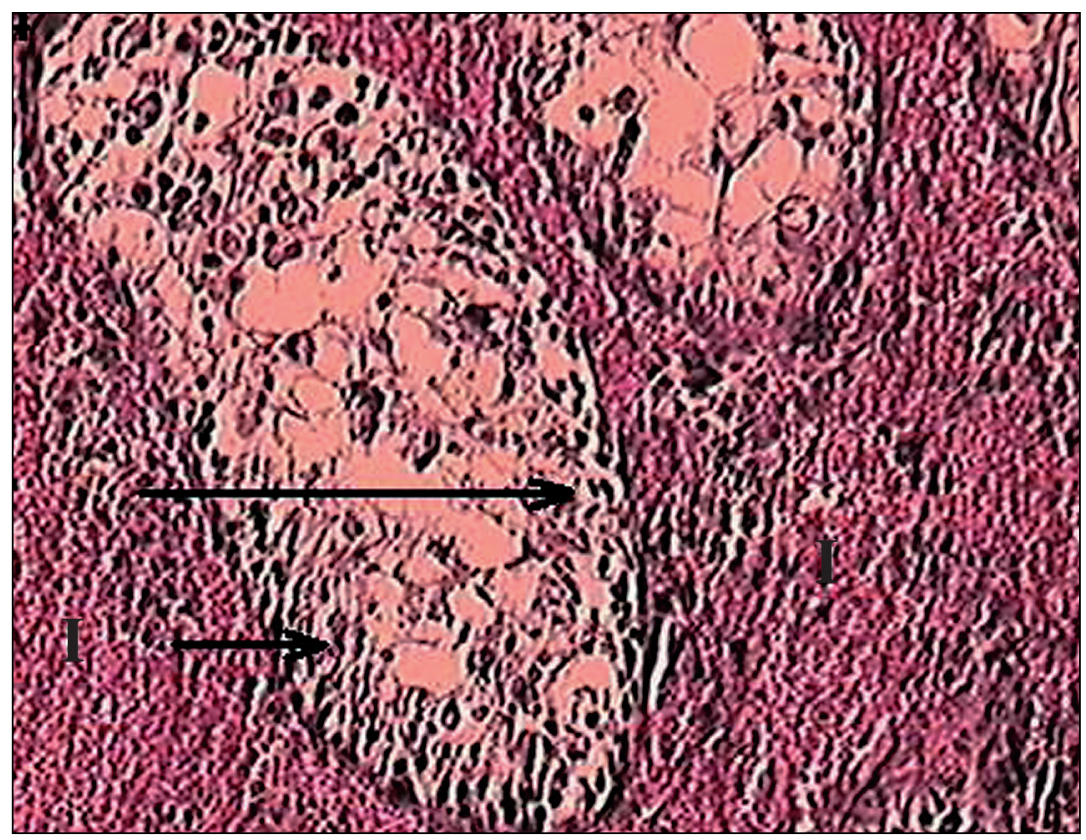

Fig. 4. Most prominent changes were detected in the group with the highest nickel concentration (group B), where the seminiferous tubules contained degenerated germinal epithelium (arrows) and the interstitium (I) was intensively infiltered mainly with eryhtrocytes. 


\section{$5 a$}

Fig. 5 a, 5 b. Immunochemical analysis detected increased apoptosis in the intersitium (arrow), in comparison with control animals.

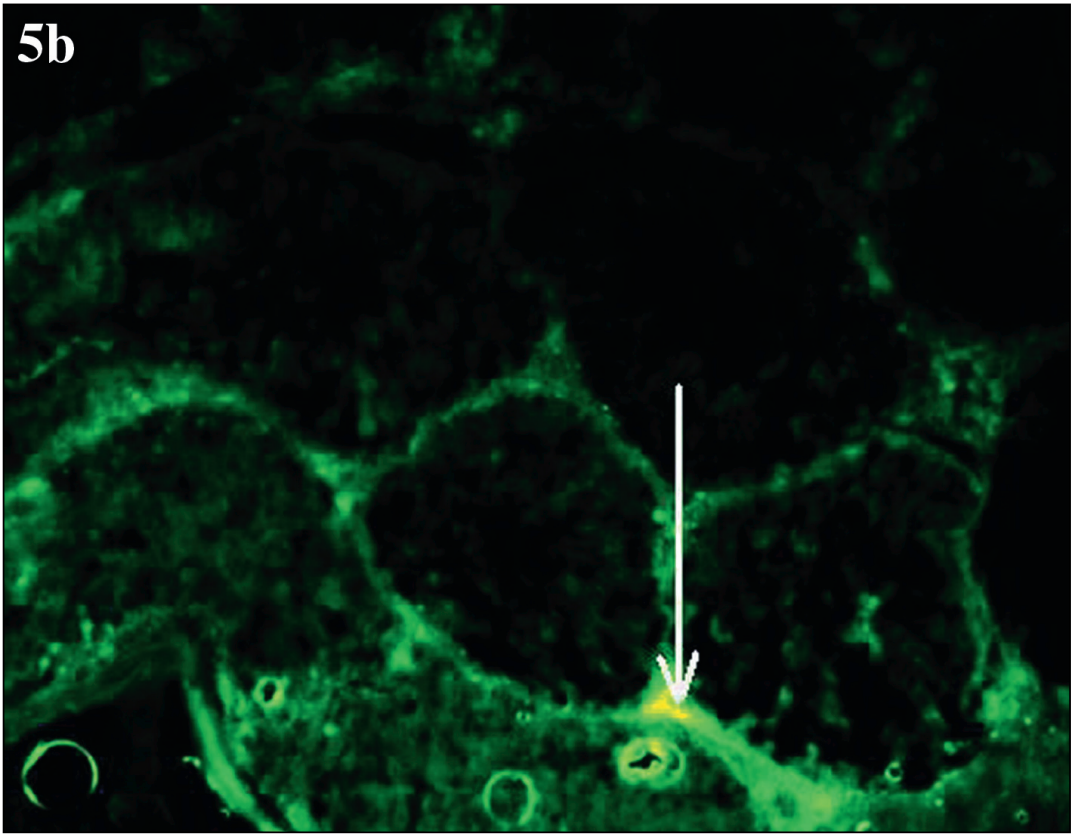

